\title{
Reabilitação precoce de atletas utilizando hidroterapia após o tratamento cirúrgico de hérnia discal lombar: relato preliminar de 3 casos
}

\author{
Early rehabilitation of athletes using hydrotherapy after surgical treatment \\ of lumbar disc herniation: preliminary report of three cases
}

\begin{abstract}
Marcelo Wajchemberg ${ }^{1}$, Leonardo Pires'², Reynaldo C. Rodrigues², Karina S. Mano², Morgana de Sá Sottomalor², Molsés Cohen ${ }^{3}$, Rene J. ABdalla ${ }^{4}$, EduARDo B. Puertas ${ }^{5}$
\end{abstract}

\section{RESUMO}

Os autores avaliaram três atletas do sexo masculino, submetidos a tratamento cirúrgico de hérnia discal lombar, com o objetivo de avaliar os resultados, após serem submetidos a um protocolo de reabilitação com base em hidroterapia. Este método permitiu a reabilitação precoce dos atletas, iniciando-se na primeira semana após a cirurgia.

Os atletas foram avaliados em 5 ocasiões: pré-operatório e nos 4 meses seguintes. Houve melhora completa da dor em dois atletas. O terceiro caso apresentou no $4^{\circ}$ mês $1,3 \%$ da intensidade máxima. As atividades de vida diária no período pré-operatório em média apresentaram-se com $21,6 \%$ da freqüência máxima, chegando a $99,3 \%$ no $4^{\circ}$ mês. A freqüência de prática esportiva teve em média $10 \%$ da intensidade no pré-operatório, no $4^{\circ}$ mês os atletas já praticavam a atividade esportiva com uma freqüência de $84,6 \%$ do normal. O nível de atividade esportiva foi relatado em média como $10 \%$ daquele estabelecido pelos atletas antes do início dos sintomas, atingindo $88,3 \%$ no $4^{\circ}$ mês.

Concluímos que os atletas apresentaram melhora evolutiva em todos os parâmetros analisados, especialmente em relação a dor. Portanto, a hidroterapia mostrou-se um método eficaz e bem tolerado na reabilitação precoce da cirurgia de hérnia discal em atletas.

Descritores: hidroterapia, hérnia discal, atletas

\section{INTRODUÇÃO}

A coluna vertebral lombar é localização freqüente de lesões, quando comparada a outros segmentos corporais na prática esportiva. Apesar deste fato, esta região muitas vezes, não recebe grande atenção da área médica, atraindo pouco interesse e consequentemente, limitada quantidade de estudos. A dor lombar tem comprovada importância entre as diversas modalidades esportivas, pois esta pode representar um problema que acarreta

\section{SUMMARY}

Three male athletes submitted to surgical treatment of lumbar disc herniation were assessed aiming to evaluate the results of a rehabilitation protocol based on aquatic therapy. This method allowed early rehabilitation of the athletes, within a week after surgery.

The athletes were evaluated in 5 occasions: pre-operatively and in the 4 following months. Complete improvement of pain was observed in two athletes. The third case had $1.3 \%$ of the maximum intensity in the $4^{\text {th }}$ month. The daily life activities during the pre-operative period presented $21.6 \%$ of the maximum frequency on average, reaching $99.3 \%$ in the $4^{\text {th }}$ month. The frequency of practicing sports was on average $10 \%$ the pre-operative intensity; in the $4^{\text {th }}$ month the athletes already played sports with a frequency $84.6 \%$ of the normal. The level of sporting activities was reported as $10 \%$ on average of the one established by the athletes before the symptoms had started, reaching $88.3 \%$ in the $4^{\text {th }}$ month.

We conclude that the athletes had an evolutionary improvement in all the analyzed parameters, especially as regards pain. Thus, hydrotherapy was an effective and well tolerated method in the early rehabilitation of athletes after disc herniation surgery.

Key Words: hydrotherapy, disc herniation, athletes.

\section{INTRODUCTION}

In the practice of sports, the lumbar vertebral column is frequent localization of lesions when compared to other body segments. In spite of that, this region often does not call medical attention, and consequently the number of studies is limited. Lumbar pain is very representative among the sports, since it is a condition which impairs performance; in order to understand it good knowledge of the column ana-
Trabalho realizado no Centro de Traumato-ortopedia do esporte (CETE) e Grupo de patologias da Coluna Vertebral - UNIFESP - EPM

1- Médico Assistente

2- Fisioterapeuta

3- Chefe do Centro

4- Coordenador Científico

5- Chefe do Grupo de Patologias da Coluna Vertebral

Endereço para correspondência: Av. Lineu de Paula Machado, 660 CEP 05601-000 - São Paulo - SP

Trabalho recebido em 20/03/2001. Aprovado em 28/03/2002

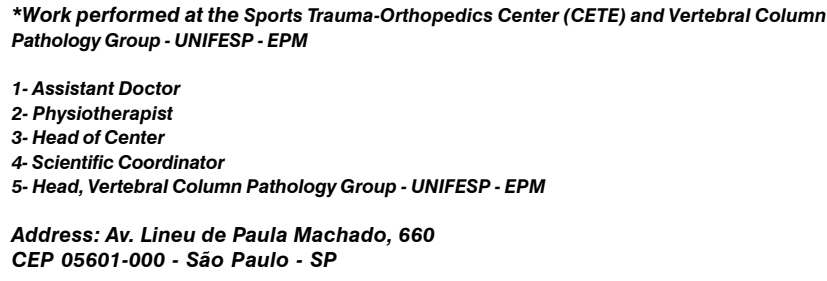


prejuízo do desempenho e para entende-la há necessidade de um bom conhecimento da anatomia e biomecânica da coluna, para a realização do diagnostico e tratamento adequados.

Foi estabelecido ${ }^{(14)}$ que estudantes que não praticavam atividade esportiva, corriam maior risco de apresentar dor nas costas em relação àqueles que eram esportistas. Apesar disto, 15\% de todas as lesões esportivas acometem a coluna vertebral ${ }^{(12)}$, não se encontrando estudos que mostrem detalhadamente a incidência de lesões especificas e sua relação com os diversos tipos de esportes. Em 1986, estudo realizado com 17 tipos de esportes, num período de 10 anos, observou-se que $80 \%$ das lesões de coluna ocorriam durante treinamentos, $6 \%$ em competições e 14\% na fase de pré-temporada. Além disso 59\% dos casos eram agudos, $12 \%$ lesões por "overuse" e 29\% em decorrência de condições pré-existentes ${ }^{(19)}$.

Analisando a literatura nota-se a carência de estudos em relação ao tratamento pós-operatório de discectomia lombar. Desta forma, o objetivo deste estudo é avaliar os resultados da aplicação de um protocolo acelerado baseado em hidroterapia, na reabilitação pós-operatória de atletas submetidos a tratamento cirúrgico para hérnia discal lombar.

\section{MATERIAIS E MÉTODOS}

Três atletas, competitivos nacionalmente, foram avaliados através de escalas visuais analógicas por ortopedistas e fisioterapeutas do Centro de Traumato-Ortopedia do Esporte (CETE) do Departamento de Ortopedia e Traumatologia da Escola Paulista de Medicina- Universidade Federal de São Paulo, no período compreendido entre outubro de 1999 a maio de 2000 na cidade de São Paulo após serem submetidos a tratamento cirúrgico de hérnia discal lombar, e receberem tratamento fisioterapêutico precoce com base em hidroterapia ${ }^{(5,27)}$

Em relação ao sexo, todos eram do sexo masculino. A idade média foi de 26,6 anos (17 a 38 anos). Dentre os atletas analisados 1 pratica basquete, 1 atletismo e 1 futebol.

\section{DIAGNÓSTICO}

Todos referiam dor lombar com irradiação para um dos membros inferiores com incapacidade completa para a prática esportiva, com sintomatologia que variava de 3 a 8 meses(média de 5,5 meses). Durante o exame físico notou-se positividadeosinal de Lasègueem 2 entre os três atletas. Somente umatletatinha diminuição do reflexo patelar eatrofia damusculatura quadricipital, não havendo alterações esfincterianas em nenhum atleta. O diagnóstico foi confirmado através da ressonância magnética $(R M)$, encontrando-se hérnia discal centro lateral esquerda em 2 pacientes e hérnia discal foraminal esquerda em 1 paciente (Figura 1), sempre no nível L4-L5. tomy and biomechanics is necessary to make adequate diagnosis and treatment.

It was established ${ }^{(14)}$ that students who did not play sports had higher risk of back pain as compared to the ones who practiced sports. In spite of that, $15 \%$ of all sport lesions occur in the vertebral column(12), and there are no studies detailing the incidence of specific lesions and their relationship with different sports. In 1986, a study with 17 modalities of sports, in a period of 10 years, has shown that $80 \%$ of the column lesions occurred during training, $6 \%$ in competitions, and $14 \%$ in the pre-season phase. Besides that, $59 \%$ of the cases were acute, $12 \%$ overuse lesions, and $29 \%$ were due to pre-existing conditions ${ }^{(19)}$.

Reviewing the literature, there are few studies related to post-surgical treatment of lumbar discectomy. The aim of this study was to evaluate the results of the application of an accelerated protocol based in hydrotherapy to the post-surgical rehabilitation of athletes submitted to surgical treatment of lumbar disc herniation.

\section{MATERIAL AND METHODS}

Three athletes, participants of national competitions, were evaluated using analogical visual scales by orthopedists and physiotherapists of the Sports Trauma-Orthopedics Center (CETE), Department of Orthopedics and Trauma, "Escola Paulista de Medicina" - Federal University of São Paulo, within October, 1999 and May, 2000 in the city of São Paulo, after being submitted to surgical treatment of lumbar disc herniation and after receiving early physiotherapeutic treatment based in hydrotherapy ${ }^{(5,27)}$.

They were 17 to 38 year-old males. Mean age was 26.6 years. One was a basketball player, 1 practiced athletism and 1 played football.

\section{DIAGNOSIS}

The athletes complained of back pain irradiating to the lower limbs with complete disability to practice sports, the symptomatology varying from 3 to 8 mon-

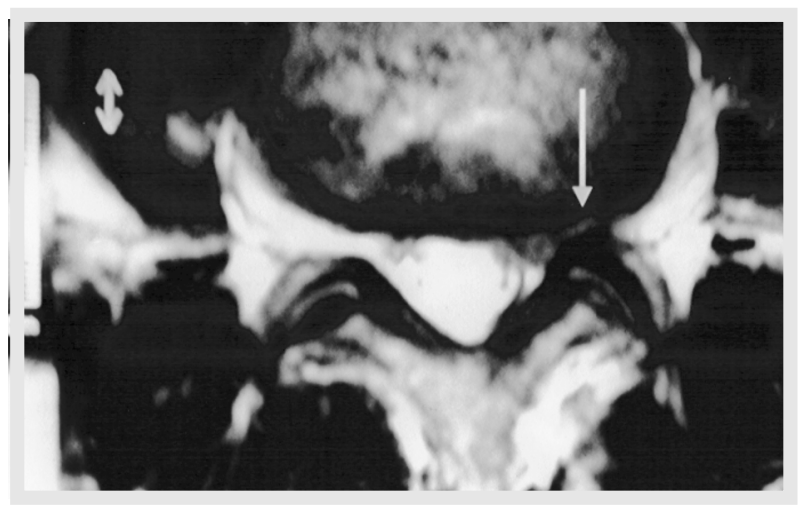

Figura 1 - Ressonância Magnética ilustrando hérnia foraminal à esquerda.

Figure 1 - Magnetic Ressonance showing foramen herniation at left. ths (mean 5.5 months). During the physical examination, the Lasègue sign was positive in 2 of the 3 athletes. Only one presented decreased patellar reflex and athrophy of the quadriceps muscles. None of the athletes presented sphincter alterations. Diagnosis was confirmed by magnetic ressonance (RM) and left central lateral disc herniation was found in 2 patients and left foramen disc herniation in 1 patient (Figure 1), always at the L4$L 5$ level. All the patients had been clinically treated with analgesics and anti-inflammatory medicati- 
Todos os pacientes já haviam sido tratados clinicamente com a utilização de medicação analgésica e anti-inflamatória e fisioterapia com melhora parcial, não permitindo ao atleta retornar às atividades competitivas.

\section{TÉCNICA CIRÚRGICA}

Todos os pacientes foram operados por via posterior (Figura 2), com incisão longitudinal entre os processos espinhosos de L4 e L5, com incisão e delicado

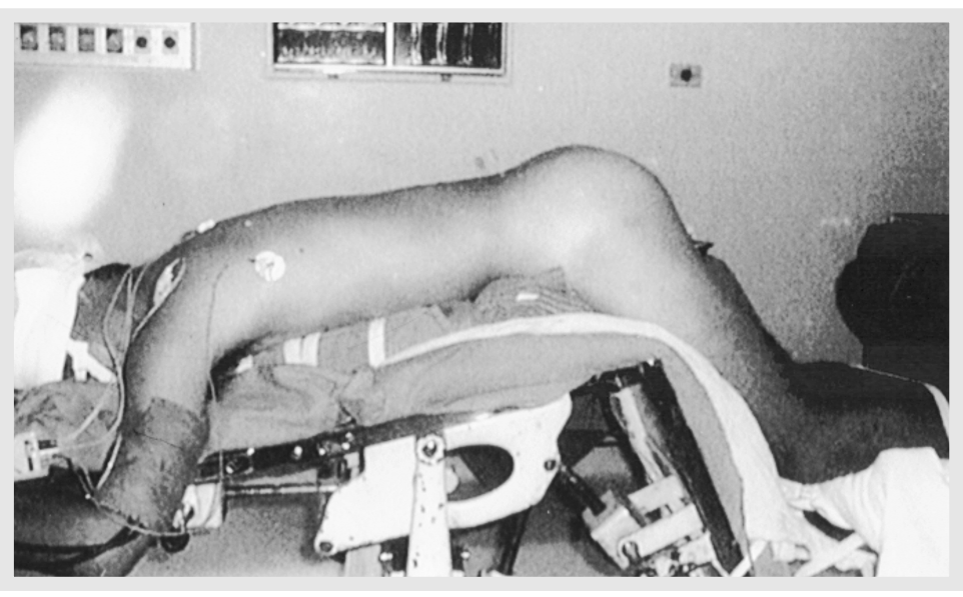

Figura 2 - Posicionamento dos pacientes na mesa de cirurgia.

Figure 2 - Position of the patients during surgery. on and physiotherapy showing partial improvement; they were not allowed to resume their competitive activities.

\section{SURGICAL TECHNIQUE}

All the patients were operated on through the posterior via (Figure 2) with longitudinal incision between the $L 4$ and $L 5$ spinal processes, with incision and delicate avertion of the unilateral paravertebral muscles until approaching the respective lamina. Partiafastamento da musculatura paravertebral unilateral, até abordagem da respectiva lâmina. Realizou-se laminotomia parcial unilateral, preservando-se a faceta articular, a seguir, incisou-se o ligamento amarelo, visibilizando-se o saco dural e isolando a raiz nervosa. Através de cuidadoso afastamento da raiz nervosa foi possível identificar a hérnia discal que foi ressecada. Após a retirada da hérnia discal foi realizada a foraminectomia.

\section{TRATAMENTO FISIOTERAPÊUTICO}

Todos os atletas foram submetidos a um mesmo protocolo de tratamento fisioterapêutico ${ }^{(5,27)}$ (Apêndice 1). O protocolo foi predominante em hidroterapia, onde no segundo pós-operatório, os atletas iniciaram a reabilitação na água com curativo adesivo impermeável sobre os pontos cirúrgicos. O tratamento foi realizado diariamente, com um tempo médio de 90 minutos por sessão. O retorno ao esporte foi realizado de forma gradativa a partir da $9^{\circ}$ semana, chegando no máximo a 13 semanas.

\section{AVALIAÇÃO DA EVOLUÇÃO DOS ATLETAS}

A avaliação foi realizada utilizando escalas visuais analógicas (3) (variando de 0 a 10, ou seja, de $0 \%$ a 100\% onde o valor máximo equivale ao normal exceto na intensidade de dor), verificando-se 4 parâmetros: freqüência de prática esportiva, nível de atividade esportiva, atividades de vida diária (AVD) e intensidade da dor. Os atletas foram avaliados em 5 momentos: pré operatório e nos 4 meses seguintes. Os resultados foram considerados bons quando todos os parâmetros ao final do $4^{\circ}$ mês atingiram proporções semelhantes ou iguais àquelas anteriores a lesão. Os resultados ruins foram considerados como aqueles parâmetros que ao $4^{\circ}$ mês, apresentavam grande déficit em relação aos parâmetros relatados no período anterior à lesão. al unilateral laminotomy was effected, preserving the articular facet, and afterwards an incision was made in the yellow ligament, revealing the dural sac and isolating the nerve root. Carefully averting the nerve root, it was possible to identify the disc herniation and proceed to ressection. After this, foraminectomy was carried out.

\section{PHYSIOTHERAPEUTIC TREATMENT}

All the athletes were submitted to the same protocol of physiotherapeutic treatment ${ }^{(5,27)}$ (Appendix 1). The predominant protocol was hydrotherapy, the athletes beginning rehabilitation in the water with an impermeable adhesive tape covering the surgical suture. Treatment was daily effected with sessions of $90 \mathrm{mi}-$ nutes on average. Sports were resumed gradatively after the $9^{\text {th }}$ week, and totally after 13 weeks.

\section{EVOLUTION OF THE ATHLETES}

Evaluation was carried out using analogical visual scales ${ }^{(3)}$ (from 0 to 10 , that is, $0 \%$ to $100 \%$, the maximum value equivalent to normal, except for pain intensity), observing 4 parameters: frequency of practice, sports activity level, daily life activities (AVD) and pain intensity. The athletes were evaluated in 5 moments: before surgery and during the 4 subsequent months. The results were considered good when all the parameters at the end of the $4^{\text {th }}$ month reached proportions similar or equal to those before the lesion occurrence. The bad results were considered those parameters that after 4 months showed great deficit as concerns the parameters reported in the period preceding the lesion.

\section{RESULTS}

Analyzing the cases as a whole, the daily life activities (chart 1) that in the pre-operative period presented on average $21.6 \%$ of the maximum frequency, reached $43.3 \%$ in the $1^{\text {st }}$ 


\section{FASE I ( $1^{\text {a }}$ semana):}

- Eletroanalgesia (TENS/corrente interferencial vetorial)

- Hidroterapia (2аP0):

- Caminhada: frente, costas e lateral

- Alongamentos para musculatura de tronco e membros inferiores

com evolução gradativa para ísquio - tibiais

- Início do treino proprioceptivo

- Exercícios isotônicos livres para membros superiores

- Exercícios isométricos para membros inferiores e musculatura abdominal

- Relaxamento global (Bad - Ragaz/final da sessão)

Obs: Evitar movimentos rotacionais

FASE II $\left(2^{\mathrm{a}}\right.$ e $3^{\mathrm{a}}$ semanas):

- Hidroterapia :

- Exercícios isotônicos livres ( $2^{\mathrm{a}}$ semana) e resistidos ( $3^{\mathrm{a}}$ semana)

para membros inferiores e musculatura abdominal

- Corrida em piscina profunda

- Manutenção dos alongamentos com ênfase para ísquio-tibiais

- Movimentos simulando bicicleta

- Início de trote

- Evolução do treino proprioceptivo

- Exercícios isotônicos resistidos para membros superiores

- Relaxamento global (Bad - Ragaz/final da sessão)

Obs: Evitar movimentos rotacionais

\section{FASE III (4⿳亠口冋 a $8^{\mathrm{a}}$ semanas):}

-Hidroterapia

- Corrida em piscina profunda

- Batimento de pernas

- Evolução de exercícios isotônicos resistidos para ísquio- tibiais

- Evolução do trote (resistência elástica)

- Corrida de frente, costas, lateral, em círculos e em oito

- Saltos leves ( (4 a semana), moderados ( $5^{\mathrm{a}}$ semana) e fortes ( $6^{\mathrm{a}}$ semana)

- Ênfase no alongamento de cadeia posterior e fortalecimento

de musculatura abdominal

- Início do treino específico do esporte (4a semana)

- Progressão do treino proprioceptivo dentro da água

- Relaxamento global (Bad - Ragaz/final da sessão)

- Trote ( $5^{\mathrm{a}}$ semana) e corrida ( $6^{\mathrm{a}}$ semana) na grama

- Início do treino proprioceptivo fora da água

- Bicicleta ergométrica

FASE IV (a partir da $9^{\mathrm{a}}$ a $12^{\mathrm{a}}$ semana):

- Énfase no treino proprioceptivo

- Enfase no treino específico do esporte

- Bicicleta ergométrica

- Retorno ao esporte (nível não competitivo)

FASE V (13 ${ }^{\mathrm{a}}$ semana)

- Retorno ao esporte de nível competitivo

\section{PHASE I(1st week):}

- Electricanalgesia (TENS/vectorial interferencial current)

- Hydrotherapy (2nd PO):

- Walking: front, back and lateral

- Stretching for the trunk and lower limbs muscles with gradative

evolution for the ischio-tibial.

- Beginning of proprioceptive training

- Free isotonic exercises for the upper limbs

- Isometric exercises for the lower limbs and abdominal muscles

- Global loosening (Bad-Ragaz/end of session)

Obs: Avoid rotation movements

PHASE II (2nd and 3rd weeks):

- Hydrotherapy:

- Free isotonic exercises (2nd week) and with resistance

( $3^{\text {rd }}$ week) for the lower and abdominal muscles

- Running - deep swimming pool

- Maintenance of stretching emphasizing ischio-tibial

- Movements simulating a bicycle

- Start jogging

- Evolution of the proprioceptive training

- Isotonic exercises with resistance for the upper limbs

- Global loosening (Bad-Ragaz/end of session)

Obs: Avoid rotation movements

PHASE III (4th to 8th weeks):

- Hydrotherapy:

- Running in deep swimming-pool

- Leg movements

- Evolution of isotonic exercises with resistance for the ischio tibial

- Evolution of jogging (elastic resistance)

- Running front, back, lateral, making circles

- Light jumping (4th week), moderate (5th week)

and intense ( $6^{\text {th }}$ week)

- Emphasis in stretching and strengthening of the abdominal muscles

- Begin training specific for the modality (4theek)

- Progression of the proprioceptive training inside water

- Global loosening (Bad - Ragaz/end of session)

- Jogging (5th week) and running (6th week) on the grass

- Begin the proprioceptive training out of the water

- Ergometric bicycle

PHASE IV (9th to 12th weeks):

- Emphasis on the proprioceptive training

- Emphasis on the training specific for the modality

- Ergometric bicycle

- Resuming sports (non-competitive level)

PHASE V (13th week):

-Resuming sports competitive level

Apêndice 1 - Protocolo fisioterapêutico pós tratamento cirúrgico de hérnia discal lombar.

Appendix 1 - Physiotherapeutic protocol after surgical treatment of the lumbar disc hernia. 


\section{RESULTADOS}

Analisando os casos de forma conjunta, as atividades de vida diária (Gráfico 1) que no período pré operatório em média apresentavam-se com $21,6 \%$ da freqüência máxima, chegaram a 43,3\% no $1^{\circ}$ mês, 84\% no $3^{\circ}$ mês e a 99,3\% no $4^{\circ}$ mês após a cirurgia. A dor (Gráfico 2), segundo relato dos atletas durante avaliação, apresentava intensidade de $83 \%$ no período pré operatório. Este sintoma foi totalmente resolvido em dois casos, sendo o primeiro no $2^{\circ}$ mês e o outro no $3^{\circ}$ mês. O terceiro caso apresentava $1,3 \%$ da intensidade máxima durante avaliação no $4^{\circ}$ mês. A freqüência de prática esportiva (Gráfico 3) teve em média $10 \%$ da intensidade no pré operatório, obtendo 40,6\% no $1^{\circ}$ mês. No $4^{\circ}$ mês os atletas já praticavam a atividade esportiva com uma freqüência de $84,6 \%$ do normal. O nível de atividade esportiva (Gráfico 4) foi relatado em média como $10 \%$ daquele estabelecido pelos atletas antes do início dos sintomas, atingindo $50 \%$ no $3^{\circ}$ mês e $88,3 \%$ no $4^{\circ}$ mês.

Considerando-se os casos de forma individual constatou-se:

\section{Atleta I}

Atleta do sexo masculino, 17 anos, praticante de basquetea 8 anos.

Na avaliação pré-operatória praticava a atividade esportiva com apenas $10 \%$ da frequência máxima. Realizava suas AVD'S com $85 \%$ de limitação. Além disso, o esporte era praticado com somente $10 \%$ da intensidade máxima e a dor, segundo o atleta, apresentava-se próxima de 100\%. O atleta após a cirurgia, obteve melhora gradativa dos parâmetros, sendo que no $1^{\circ}$ mês apresentava-se com $2 \%$ da intensidade de dor relatada antes da cirurgia. No $2^{\circ}$ mês já realizava todas as AVD'S e não apresentava quadro álgico.

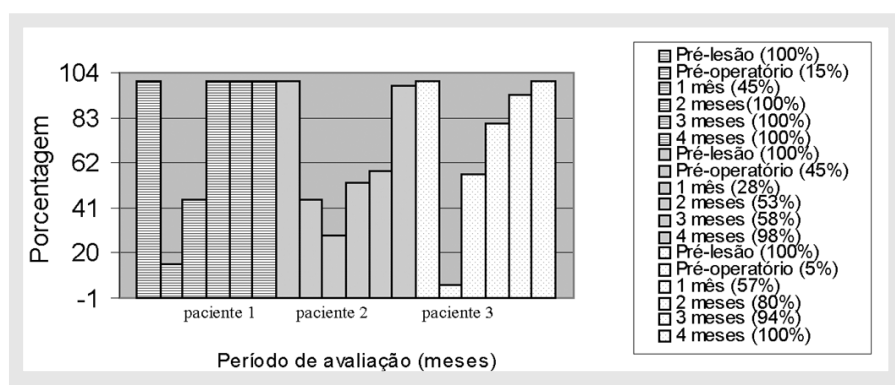

Gráfico 1 - Atividades de vida diária. Chart 1 - Daily life activities.

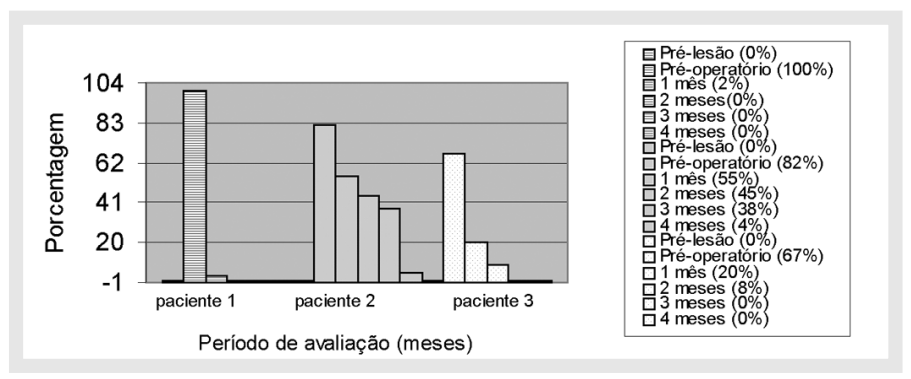

Gráfico 2 - Intensidade de dor. Chart 2 - Pain intensity.

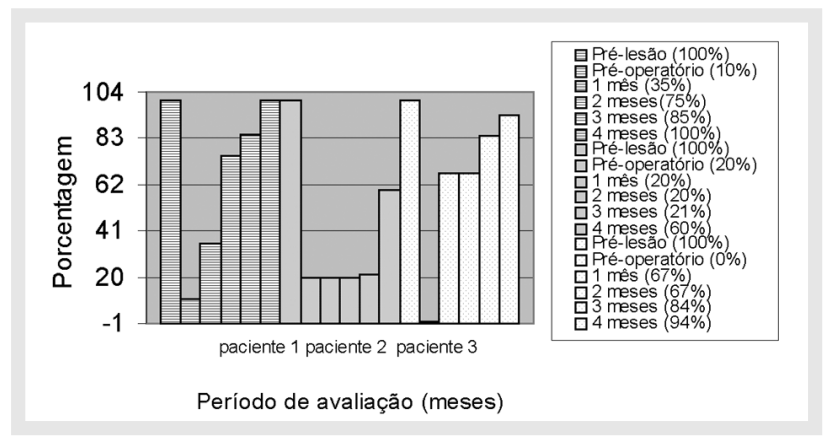

Gráfico 3 - Freqüência de prática esportiva.

Chart 3 - Frequency of sports practice.

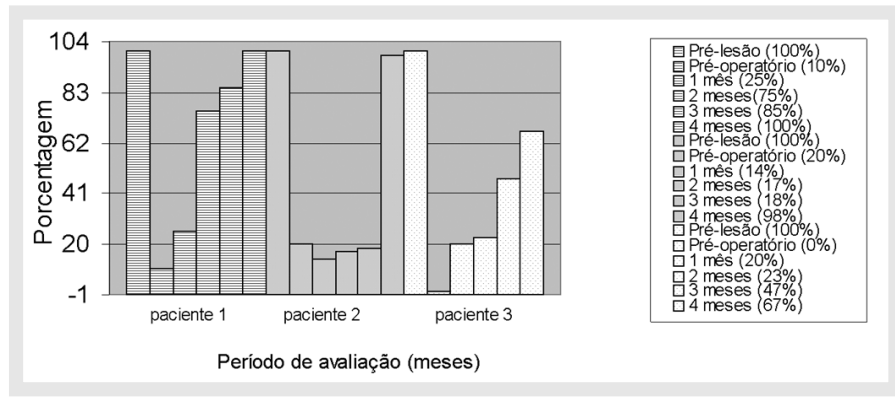

Gráfico 4 - Nível de atividade esportiva. Chart 4 - Sports activity level. month, $84 \%$ in the $3^{r d}$ month, and $99.3 \%$ in the $4^{\text {th }}$ month after surgery. Pain (chart 2), according to the athletes, presented a $83 \%$ intensity in the pre-operative period. This symptom was totally resolved in two cases, in the $2^{\text {nd }}$ month and in the $3^{\text {rd }}$ month, respectively. The third case presented $1.3 \%$ of the maximum intensity during the $4^{\text {th }}$ month evaluation. Frequency of sport practice (chart 3) presented on average $10 \%$ of the pre-operative intensity, $40.6 \%$ in the $1^{\text {st }}$ month. In the $4^{\text {th }}$ month the athletes were able to practice sports with a frequency $84.6 \%$ of the normal. The sports activity level (chart 4) was reported as on average $10 \%$ of the one established by the athletes before the appearance of the symptoms, reaching $50 \%$ in the $3^{\text {rd }}$ month and $88.3 \%$ in the $4^{\text {th }}$ month.

Considering the cases individually it was found that:

\section{Athlete I}

A seventeen year-old male athlete practicing basketball for 8 years. In the pre-operative evaluation he practiced sports with only $10 \%$ of the maximum frequency. AVDs were practiced with $85 \%$ limitation. Besides that, sports were played with only $10 \%$ of maximum intensity and, according to the athlete, pain was near $100 \%$. After surgery, gradual improvement was observed in the parameters, in the $1^{\text {st }}$ month with $2 \%$ pain intensity reported before surgery. In the $2^{\text {nd }}$ month, all AVDs were carried out without any pain. Frequency of sports practice and sports activity level at the $3^{\text {rd }}$ month presented only $15 \%$ deficit and at the $4^{\text {th }}$ month they were complete. 
A frequência de prática de esporte e o nível de atividade esportiva ao $3^{\circ}$ mês apresentavam apenas $15 \%$ de déficit e ao $4^{\circ}$ mês foram completas.

\section{Atleta II}

Atleta do sexo masculino, 38 anos, praticante de atletismo a 17 anos.

No período pré-operatório praticava a atividade esportiva com $20 \%$ da frequência máxima. Realizava $45 \%$ das AVD'S e praticava o esporte com $20 \%$ da intensidade máxima. A dor apresentava-se com $82 \%$ do máximo relatado pelo atleta. No $1^{\circ}$ mês a dor apresentava 55\% de intensidade. No $4^{\circ}$ mês as AVD'S foram realizadas normalmente em $98 \%$ dos casos, a freqüência de prática foi de $60 \%$ e o nível de atividade chegou a $98 \%$ da intensidade máxima. A dor representava apenas $4 \%$ da intensidade inicial.

\section{Atleta III}

Atleta do sexo masculino, 25 anos, praticante de futebol a 12 anos.

No período prévio à cirurgia o atleta não praticava nenhum tipo de atividade esportiva e realizava somente $5 \%$ de suas AVD'S. A dor representava $67 \%$ da intensidade máxima. Já no $1^{\circ}$ mês a freqüência de prática esportiva foi de $67 \%$, porém com $20 \%$ da intensidade máxima. A dor representava $20 \%$ e as AVD'S eram realizadas em $57 \%$ dos casos. A dor foi totalmente eliminada no $3^{\circ}$ mês. No $4^{\circ}$ mês o atleta praticava o esporte com $94 \%$ da freqüência prévia à lesão, 67\% da intensidade máxima e realizava todas as AVD'S sem qualquer queixa.

\section{DISCUSSÃO}

O tratamento cirúrgico de hérnia discal lombar é descrito desde $1934^{(15-25)}$. Na Alemanha cerca de 20.000 pacientes (10) e nos Estados Unidos da América 200.000 procedimentos de discectomia ocorrem por ano ${ }^{\left({ }^{33}\right)}$. Os pacientes submetidos a este procedimento geralmente possuem idade acima de 40 anos, porém 1-3\% destas cirurgias são realizadas em indivíduos com idade inferior a 21 anos ${ }^{(9-30)}$. No presente estudo os pacientes submetidos ao tratamento cirúrgico são atletas de alto nível, característica que limita grande quantidade de trabalhos, já que este assunto é pouco relatado na literatura.

Existem 2 formas distintas para o tratamento de hérnia discal lombar: (1) o tratamento conservador onde o paciente é submetido a repouso, uso de antiinflamatórios, manipulações e outras diversas modalidades de fisioterapia; e (2) o tratamento cirúrgico seguido de reabilitação.

A reabilitação, após tratamento cirúrgico de hérnia discal, possui grande variação em diversos trabalhos. Em 1993 (23) utilizaram 2 modelos. O primeiro modelo utilizava um programa de alta intensidade onde exercícios abdominais e de extensão da coluna eram realizados conforme limite doIoroso do próprio paciente. O segundo, tradicional, visava ganho de amplitude de movimento a partir de exercícios leves e progressivos conforme desenvolvimento do paciente. Ambos iniciavam-se na $5^{\mathrm{a}}$ semana após a cirurgia e

\section{Athlete II}

A thirty-eight year-old male athlete, practicing athletism for 17 years. In the pre-operative period he played sports with $20 \%$ maximum frequency. AVDs were practiced $45 \%$, and sports with $20 \%$ of maximum intensity. Pain was $82 \%$ of the maximum reported by the athlete. Ind the $1^{\text {st }}$ month, pain presented $55 \%$ intensity. In the $4^{\text {th }}$ month, AVDs were normally carried out in $98 \%$ of the cases, the frequency of practice being $60 \%$ and the activity level reaching $98 \%$ of the maximum intensity. Pain represented only $4 \%$ of the initial intensity.

\section{Athlete III}

A twenty-five year-old male athlete, practicing football for 12 years. In the period before surgery, the athlete was not practicing any sports activity and carried out only $5 \%$ of his AVDs. Pain represented $67 \%$ of the maximum intensity. In the $1^{\text {st }}$ month, the frequency of sports practice was $67 \%$, however with $20 \%$ of the maximum intensity. Pain represented $20 \%$ and AVDs were carried out in $57 \%$ of the cases. Pain was totally absent in the $3^{\text {rd }}$ month. In the $4^{\text {th }}$ month, the athlete practiced sports with $94 \%$ of the frequency previous to the lesion, $67 \%$ of the maximum intensity and all AVDs were carried out with no complaints.

\section{DISCUSSION}

The surgical treatment of the lumbar disc herniation is described since 1934(15-25). In Germany, about 20,000(10) and in the United States of America 200,000 discectomy procedures are effected during one year ${ }^{(33)}$. The patients submitted to this procedure in general are older than 40 years, however $1-3 \%$ of the surgeries are carried out in individuals below the age of $21^{(9-30)}$. In this study, the patients submitted to surgical treatment are elite athletes, and this characteristic limitates the number of studies since the subject is scarce in the scientific literature.

There are 2 distinct forms of treatment for the lumbar disc herniation: (1) the conservative treatment submits the patient to rest, uses anti-inflammatory drugs, manipulations and several other modalities of physiotherapy; and (2) surgical treatment followed by rehabilitation.

Rehabilitation, after surgical treatment, is differently considered in different studies. In 1993(23) two models were used. The first model recommended a high intensity program with abdominal exercises and column extension, according to the patient's limit of pain. The second, traditional, aimed to increase the amplitude of movements with light and progressive exercises, according to the patient's development. Both ought to start in the $5^{\text {th }}$ week after surgery and were maintained during 6 weeks. In 1996(7) early mobilization was instituted, the patient progressively exerting the activities, according to his possibilities (without restrictions). In a recent stu$d y^{(8)}$, early rehabilitation was suggested beginning 4 weeks after surgery. The exercises are exclusively active aiming to strengthen the column muscles, the abdominal muscles and the lower limb muscles. In $1999^{(34)}$ elite athletes participated of a conservative protocol based in modification of activities, physiotherapy (ice, ultrasound, electric stimulation, etc.) lum- 
eram mantidos por 6 semanas. Em $1996{ }^{(7)}$ utilizaram mobilização precoce, onde o paciente realizava as atividades progressivamente de acordo com suas possibilidades (sem restrições). Em estudo recente, ${ }^{(8)}$ sugeriram a reabilitação precoce com início 4 semanas após a cirurgia. Os exercícios são exclusivamente ativos com o objetivo de fortalecer os músculos da coluna, abdominais e músculos dos membros inferiores. Em $1999{ }^{(34)}$ utilizaram em atletas de elite, um protocolo conservador baseado em modificação de atividades, fisioterapia (gelo, ultra-som, eletroestimulação, etc), órtese lombar, anti-inflamatórios não hormonais (AINH) e um programa de orientação postural. Em nosso estudo apresentamos um protocolo embasado em hidroterapia com início precoce da reabilitação ${ }^{(5,27)}$. $\mathrm{Na} 1^{\mathrm{a}}$ semana, alongamentos, exercícios de relaxamento e isométricos para mem-

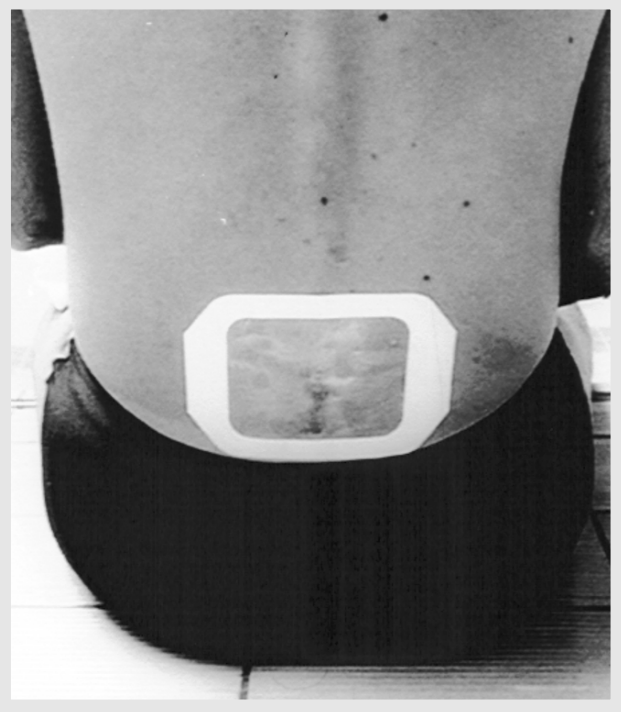

Figura 3 - Proteção impermeável utilizada para realização de hidroterapia na $1^{a}$ semana de pós-operatório.

Figure 3 - Impermeable protection used to practice hydrotherapy in the $1^{\text {st }}$ week post-surgery. bar orthesis, non-hormonal anti-inflammatory drugs (AINH), and a postural orientation program. In our study, we present a protocol based in hydrotherapy with early rehabilitation ${ }^{(5,27)}$. In the $1^{\text {st }}$ week, stretching, loosening, and isometric exercises for the lower limbs and abdominal muscles are carried out inside the water and, after the $9^{\text {th }}$ week, the athlete resumed the sports activities. The main objective is to maintain the sports activity characteristics and promote muscular and proprioceptive equilibrium, providing early resuming of sports at an activity level close to that established before the lesion occurrence.

Some factors can influence the surgical treatment results. The kind of rehabilitation offered during the post-operative period favors good results but can also deteriorate them ${ }^{(17)}$. In a study within 1988 and 1991, it was shown that intensive exercises for the column were pribros inferiores e musculatura abdominal são realizados dentro da água e a partir da $9^{a}$ semana, o atleta começa a retornar à atividade esportiva. O objetivo maior é manter características da atividade esportiva e promover um reequilibro muscular e proprioceptivo, propiciando o retorno precoce ao esporte no nível de atividade mais próximo daquele estabelecido no período prévio à lesão.

Alguns fatores podem influenciar os resultados do tratamento cirúrgico. O tipo da reabilitação oferecida no período pós-operatório, favorece bons resultados como também pode deteriorálos ${ }^{(17)}$. Em um estudo realizado entre 19881991, ficou demonstrado que, exercícios intensivos para a coluna foram primordiais tanto para a redução nas dores lombares, como também para os resultados satisfatórios do tratamento(23). Sugerem ${ }^{(7)}$ que restrições no período pós-operatório não são necessárias, pois pacientes submetidos a este tipo de conduta, permanecem menor tempo afastados das atividades e ao retornar não apresentam complica-

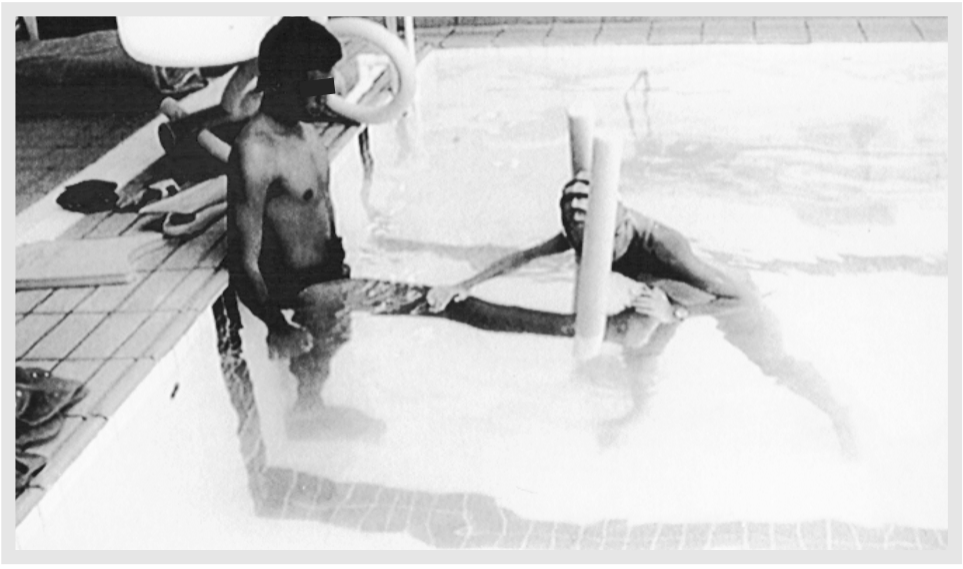

Figura 4 - Exercício para alongamento de musculatura posterior de coxa.

Figure 4 - Exercise to stretch the posterior muscles of the thigh. mordial not only to reduce lumbar pain but also to produce satisfactory results to the treatment ${ }^{(23)}$. It is suggested ${ }^{(7)}$ that restrictions during the post-operative period are not necessary since the patients submitted to this conduct stay far from the activities longer and when they return they do not present complications. So, the protocol used in this study focuses early rehabilitation through hydrotherapy in which physical properties as floating reduce the compressive and shearing forces on the column, allowing early realization of exercises in a safe environment without overload ${ }^{(6-4)}$. Aquatic exercises begin in the $1^{\text {st }}$ week post-surgery (Figure 3) aiming postural orientation and improved flexibility (Figure 4), strength, resistance and muscular function, emphasizing the abdominal (Figure 5) and paravertebral $(6,28,4)$ muscles. At the beginning of the rehabilitation, rotation movements are avoided due to the paravertebral muscles deficiency that in this moment provides little stabilization to the column ${ }^{(35,3)}$. This early rehabilitation without any impact aims to avoid the deleterious effects of rest as altera- 
ções. Desta forma, o protocolo utilizado neste trabalho enfoca a reabilitação precoce, utilizando hidroterapia onde as propriedades físicas como a flutuação, reduzem as forças compressivas e de cisalhamento na coluna, permitindo a realização precoce de exercícios em um ambiente seguro e isento de sobrecargas ${ }^{(6-4)}$. Os exercícios aquáticos iniciam-se na $1^{\circ}$ semana de pós-operatório (Figura 3), com objetivos de orientações posturais, além de melhorar flexibilidade (Figura 4), força, resistência e função muscular, com ênfase para musculatura abdominal (Figura 5) e paravertebral ${ }^{6-}$ 28-4). No início da reabilitação evitam-se os movimentos rotacionais em decorrência da deficiência da musculatura paravertebral que neste momento, proporciona pouca estabilização à coluna ${ }^{(35-3)}$. Esta reabilitação precoce, porém sem impacto, visa evitar efeitos deletérios do repouso como a alteração da composição das fibras musculares da coluna lombar ${ }^{(18)}$ e, principalmente, propicia ao atleta, um tratamento dentro dos padrões encontrados em sua atividade esportiva. Para isso com o decorrer do protocolo, as atividades se tornam um tanto quanto funcionais, simulando as atividades esportivas realizadas previamente. Por exemplo, no basquete tabelas com cestas são adaptadas às bordas da piscina e antes de retornar à prática fora da água o atleta exercita os movimentos básicos do esporte como saltos, corrida, deslocamentos (Figura 6) e arremessos. No atletismo, o atleta inicia a corrida na piscina e posteriormente retoma os treinos fora da água.

O tratamento cirúrgico em geral apresenta bons resultados. Em $1991^{(1)}$, estabeleceram que os resultados obtidos após discetomia, foram satisfatórios em $80 \%$ dos casos. Já estabelecem ${ }^{(11)}$ cerca de $96 \%$ de bons e excelentes resultados. Analisando o tratamento cirúrgico em pacientes abaixo de 21 anos, demonstram (31) $77 \%$ de alívio da dor e $85 \%$ de satisfação por parte dos pacientes. Em relação ao tratamento de atletas, concluíram ${ }^{(34)}$ que $90 \%$ destes retornaram a competições de alto nível. O tratamento conservador segundo, apresenta $90 \%$ de bons e excelentes resultados (29). Em $1983^{(36)}$, analisou prospectivamente, 280 pacientes com hérnia discal, comparando o tratamento cirúrgico ao conservador. Com 1 ano de acompanhamento, os pacientes tratados de forma conservadora, apresentavam $61 \%$ de resultados satisfatórios; os tratados de forma cirúrgica obtiveram maior proporção de resultados satisfatórios (80\%). Com 10 anos os resultados foram similares entre o grupo tratado de forma conservadora e cirúrgica. Os resultados tion of the composition of the lumbar column muscle fibers ${ }^{(18)}$ and, mainly, provides the athlete a treatment inside the standards found in his sports activity. During the protocol, the activities are somehow functional, simulating the sports activities previously performed. For instance, in basketball, the baskets are adapted to the swimming pool margins and the athlete, before returning to his practice on the ground, exercises the basic movements of that modality as jumps, running, displacements (Figure 6) and throwing. In athletism, the athlete runs inside the swimming-pool and then he resumes training on the ground.

The surgical treatment in general presents good results. In $1991^{(1)}$, it was established that the results obtained after discectomy were satisfactory in $80 \%$ of the cases. Other authors ${ }^{(11)}$ established about $96 \%$ good and excellent results. Analyzing the surgical treatment in patients below 21 years, 77\% improvement of pain and $85 \%$ satisfaction on the part of the patients were found ${ }^{(31)}$. Considering the athletes treatment, it was concluded(34) that $90 \%$ of them resumed high level competitions. The conservative treatment presents $90 \%$ of good and excellent results ${ }^{(29)}$. In 1983(36), 280 patients with disc herniation were prospectively analyzed, and the surgical and the conservative treatments were compared. After one-year follow-up, the patients treated conservatively presented $61 \%$ of satisfactory results; the ones treated with surgery had a greater proportion of satisfactory results (80\%). After 10 years, the results were similar for the conservative and surgical groups. The results of the surgical treatment seem to deteriorate with evolution, causing recurrence of pain and symptoms in the column ${ }^{(11,16)}$. However, several studies demonstrate that the results obtained in evaluations with short follow-up are similar to those reported for long periods. In 1987(22), it was concluded that the results obtained with a one-year follow-up were as satisfactory as those obtained with 5-10 years follow-up. It was established(31) that the results deteriorate as time passes, however the mean for good results reveals a high rate of success. Thus, in spite of the good results found in this study, definitive conclusions cannot be presented since follow-up is still short and a higher number of cases is necessary to represent a more significant sample.

Literature shows better results for the surgical option at the short-term and similar results at the long-term. In this study, the option ${ }^{(36)}$ was the surgical treatment providing improvement of the symptoms and consequent possibility to resume the sports activities in a short period. The 3 analyzed patients (athletes) presented good results concerning im- 
do tratamento cirúrgico parecem deteriorar com a evolução, causando recorrência de dores e sintomas ao nível da coluna ${ }^{(11,16)}$. Porém, vários trabaIhos demonstram que os resultados obtidos em avaliações com curto período de acompanhamento são semelhantes àqueles reportados em longos perío-

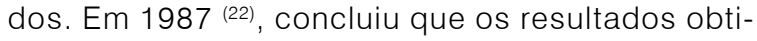
dos com 1 ano de acompanhamento, foram tão satisfatórios quanto aqueles obtidos com 5-10 anos de seguimento. Estabeleceram ${ }^{(31)}$ que os resultados deterioram com o passar do tempo, porém, a média de bons resultados permanece com alto índice de sucesso. Desta forma, apesar dos bons resultados encontrados neste estudo, não se pode obter conclusões definitivas, pois o acompanhamento ainda é curto e necessita de um número maior de casos para formar-se uma amostra mais significante.

A literatura mostra melhores resultados com a opção cirúrgica a curto prazo e resultados semeIhantes a longo prazo. A opção ${ }^{(36)}$ neste trabalho, foi o tratamento cirúrgico, o qual proporciona meIhora dos sintomas precoce aos atletas e conseqüente retorno às atividades esportivas em curto período. Os 3 pacientes (atletas) analisados, apresentaram bons resultados com melhora de sintomas e retorno às atividades de vida diária e às atividades esportivas. A dor no $1^{\circ}$ mês já apresentava $1 / 3$ da intensidade relatada no período prévio à cirurgia. As AVD'S no $2^{\circ}$ mês eram praticadas com mais de $50 \%$ da intensidade prévia à lesão. As atividades esportivas no $3^{\circ}$ mês eram praticadas com cerca de 50-60\% de intensidade quando comparada àquelas praticadas anteriormente a lesão, ao $4^{\circ}$ mês 99,3\% eram realizadas sem intercorrências. Portanto, os resultados apresentados estão de acordo com a literatura, sabendo-se que todos os atletas tratados voltaram a praticar suas atividades esportivas e atingiram em média $80-88 \%$ de intensidade no $4^{\circ}$ mês, sem relatos de dor. Deve-se considerar que os três atletas foram operados de hérnia discal em apenas um nível. Em 1999 (34) estabeleceram piores resultados na recuperação para atletas tratados cirugicamente em dois níveis.

\section{CONCLUSÕES}

Os dados sugerem bons resultados no tratamento fisioterapêutico, com hidroterapia, em pacientes submetidos a tratamento cirúrgico de hérnia discal lombar. Este trabalho é o relato preliminar de um acompanhamento permanente, que será mantido com o objetivo de somar uma maior amostra e desta maneira, evidenciar com maior clareza, aspectos relacionados com a reabilitação de atletas com hérnia discal lombar. Como destaque de aprendizado, deve-se enfatizar que a reabilitação de atletas, sempre que possível, necessita da interação entre o tratamento e o esporte praticado, visando a manutenção das características esportivas e a recuperação precoce em um ambiente, um tanto quanto

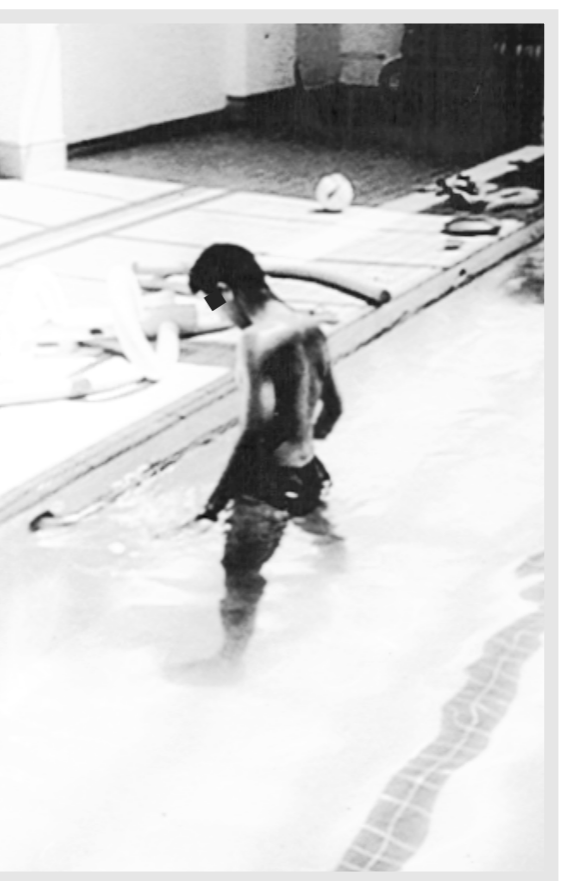

Figura 6 - Exercício simulando deslocamentos laterais.

Figure 6 - Exercise simulating lateral displacements.

provement of symptoms and resumption of daily life and sports activities. Pain in the $1^{\text {st }}$ month was already $1 / 3$ the intensity reported in the period before surgery. In the $2^{\text {nd }}$ month, the AVDs were practiced $50 \%$ more intensely as before the lesion. In the $3^{\text {rd }}$ month, the sports were practiced with about 50 $60 \%$ intensity as compared to before the lesion. In the $4^{\text {th }}$ month, 99.3\% were performed with no intercurrences. The results are consistent with the literature, since all the athletes resumed their sports activities and attained on average $80-88 \%$ intensity in the $4^{\text {th }}$ month, with no complaints about pain. One must consider that the three athletes were operated on in only one level. In 1999(34), athletes surgically treated in two levels presented worse recovery results.

\section{CONCLUSIONS}

The data suggest good results in the physiotherapeutic treatment with hydrotherapy in patients submitted to surgical treatment of lumbar disc herniation. This study is the preliminary result of a permanent follow-up which will be maintained aiming to reach a more significant sample and then to clarify aspects related to rehabilitation of athletes with lumbar disc herniation. One must emphasize that the rehabilitation of athletes, whenever possible, demands interaction between treatment and sport, aiming maintenance of the sport characteristics and early recovery in an environment somehow adapted to the sports activities. The literature shows controversies as concerns the more adequate rehabilitation for the patients, in particular athletes submitted to surgical treatment, mainly as concerns the moment to start with rehabilitation exercises. Thus, studies about that matter must be stimulated, since a uniform conduct for the post-operative rehabilitation of athletes submitted to discectomy does not exist.

The focusing of the surgical treatment for athletes and non-sport practicing patients must be different since some symptoms related to disc herniation are tolerated in the per- 
adaptado à atividade esportiva. A literatura ainda mostra controvérsia em relação ao tipo de reabilitação mais apropriada para pacientes, e em especial, atletas submetidos a tratamento cirúrgico, principalmente em relação ao início dos exercícios de reabilitação. Portanto, trabalhos referentes a esses assuntos devem ser estimulados, pois não existe ainda uma conduta uniforme para reabilitação pós-operatória de atletas submetidos à discectomia.

O enfoque em relação ao tratamento cirúrgico entre o atleta e o paciente não esportista deve ser diferente, pois alguns sintomas relacionados à hérnia discal são tolerados para a realização de atividades de vida diária, porém, incapacitam o atleta à prática esportiva, ou seja, a dor pode dificultar amplamente as atividades esportivas, porém, não interferir de forma tão ampla nas atividades de vida diária. Os critérios e limites entre a indicação do tratamento cirúrgico ou conservador não são claros, sendo necessário abordar as condições individuais de cada atleta.

\section{REFERÊNCIAS BIBLIOGRÁFICAS}

1. Abramovitz JN, Neff SR: Lumbar disc surgery: Results of the prospective lumbar discectomy study of the joint section on disorders of the spine and peripheral nerves of the American Association of Neurological Surgeons and the Congress of Neurological Surgeons. Neurosurgery 29(2):301-307, 1991.

2. Ariyoshi M, Sonoda K, Nagata K, et al: Efficacy of aquatic exercises for patients with low-back pain. Kurume Medical Journal 46:91-96, 1999.

3. Beard DJ, Dodd CAF: Home or supervised rehabilitation following anterior cruciate ligament reconstrucion: A randomized controlled trial. JOSPT 27(2):134-143, 1998.

4. Becker BE, Cole AJ: Terapia aquática moderna, Ed.1, São Paulo, Manole, 2000. 186p.

5. Brennan GP, Shultz BB, Hood RS, et al: The effects of aerobic exercise after lumbar microdiscectomy. Spine 19(7):735-739, 1994.

6. Campion MR: Hidroterapia: princípios e prática, Ed.1, São Paulo, Manole, 2000. 332p.

7. Carragee EJ, Helms E, O'Sullivan GS: Are postoperative activity restrictions necessary after posterior lumbar discectomy?. Spine 21(16):1893-1897, 1996.

8. Danielsen JM, Johnsen R, Kibsgaard SK, Hellevik E: Early aggressive exercise for postoperative rehabilitation after discectomy. Spine 25(8):1015-1020, 2000.

9. DeOrio JK, Bianco AJ: Lumbar disc excision in children and adolescents. J Bone Joint Surg [Am] 64:991-996, 1982.

10. Dvorak J, Gauchat MH, Valach L: The outcome of surgery for lumbar disc herniation. Spine 13(12):1418-1422, 1988.

11. Ebersold MJ, Ouast LM, Bianco AJ: Results of lumbar discectomy in the pediatric patient. J Neurosrg 67:643-647, 1987.

12. Eismont FJ, Kitchel SH: "Thoracolumbar spine". In Orthopaedic sports medicine : principles and practice, Pennsylvania - USA, Saunders, 1994, chapter nineteen pg. 1018-1062.

13. Epstein JA, Epstein ME, Marc J, Rosenthal AD, Lavine LS: Lumbar intervertebral disk herniation in teenage children: Recignition and management of associated anomalies. Spine 9:427-432, 1984.

14. Fairbank JC, Pynsent PB, Van Poortvliet JA, et al: Influence anthropometric factors and joint laxity in the incidence of adolescent back pain. Spine 9:461-464, 1984.

15. Frymoyer JW, Donaghy RMP: The ruptured intervertebral disc: follow-up report on the first case fifty years after recognition of the syndrome and its surgical significance. J Bone Joint Surg 67A:1113-1115, 1985.

16. Hakelius A: Prognosis in sciatica. Acta Orthop Scand 129:123-125, 1970.

17. Howe J, Frymoyer JW: The effects of questionnaire design on the determination of end results im lumbar spinal surgery. Spine 10:804-805, 1985.

18. Kalino H, Rantanen J, Viljanen T, Einola S: Lumbar muscle: structure and function. Ann Med 21:353-359, 1989. formance of the daily life activities, however, at the same time disables the athlete to the practice of sports, that is, pain can cause great difficulties to practice sports not interfering so intensely in the daily life activities. Criteria and limits to indicate surgical or conservative treatments are not very clear and it is necessary to approach the individual conditions of each athlete.

19. Keene JS, Albert MJ, Springer SL, et al: Back injuries in college athletes. J Spinal Dis 2:190-195, 1986.

20. Kesselring J: Therapie akuter lumbaler discushernien. Therapeutische Umschau 42:699-702, 1985.

21. LeFort SM, Hannah E: Return to work following na aquafitness and muscle strengthening program for the low back injuried. Arch Phys Med Rehabil 75:1247-1255, 1994

22. Lewis PJ, Weir BKA, Broad RW, Grace MG: Long-term prospective study of lumbosacral discectomy. J Neurosrg 67:49-53, 1987.

23. Manniche C, Asmussen K, Lauritsen B, et al: Intensive dynamic back exercises with or without hyperextension in chronic back pain after for lumbar disc protrusion. Spine 18(5):560-567, 1993.

24. Manniche C, Skall HF, Braendholt L, et al: Clinical trial of postoperative dynamic back exercises after first lumbar discectomy. Spine 18(1): 92-97, 1993.

25. Mixter WJ, Barr JS: Rupture of intervertebral disc with involvement of spinal canal. N Engl J Med 211:210-214, 1934.

26. Norm A, Hanson B: Exercícios aquáticos terapêuticos, Ed.1, São Paulo, Manole, 1998. 320p.

27. Prins J, Cutner D: Aquatic therapy in the rehabilitation of athletic injuries. Clinics in Sports Medicine 18(2):447-61, 1999 Apr.

28. Ruoti RG, Morris DM, Cole AJ: Reabilitação aquática, Ed.1, São Paulo, Manole, 2000. 463p.

29. Saal AJ, Saal AJ: Nonoperative treatment of herniated lumbar intervertebral disc with radiculopathy. Spine 14:431-437, 1989.

30. Savini R, Martucci E, Nardi S, Capelli A, Gusella A: The herniated lumbar intervertebral disc in children and adolescents. Ital J Orthop Traumatol 17:505-511, 1991.

31. Silvers HR, Lewis PJ, Clabeaux DE, Asch HL: Lumbar disc excisions in patients under the age of 21 years. Spine 19(21):2387-2392, 1994.

32. Skinner AT, Thomson AM: Duffield: exercícios na água, Ed.3, São Paulo, Manole, 1985. 210p.

33. Taylor VM, Deyo RA, Cherkin DC, Kreuter W: Low back pain hospitalization: Recent United States trends and regional variations. Spine 19:1207-1213, 1994.

34. Wang JC, Shapiro MS, et al: The outcome of lumbar discectomy in elite athletes. Spine 24(6):570-573, 1999.

35. Watkins RG, Buhler W: "Water workout program". In (The Spine in sports), St. Louis - USA, Mosby, 1996, p.271-282.

36. Weber $\mathrm{H}$ : Lumbar disc herniation: A controlled, prospective study with tem years of observation. Spine 8:131-140, 1983. 